\title{
Comparative study of leg wound skin closure in coronary artery bypass graft operations
}

\author{
GD ANGELINI, EG BUTCHART, SH ARMISTEAD, IM BRECKENRIDGE \\ From the Department of Cardiothoracic Surgery, University Hospital of Wales, Cardiff
}

ABSTRACT A prospective randomised study of four different methods of leg wound skin closure after removal of the long saphenous vein was carried out in 113 patients undergoing coronary artery bypass grafting. These methods were: (1) continuous nylon vertical mattress suture (27 patients); (2) continuous subcuticular absorbable (Dexon) suture (29 patients); (3) metal skin staples (Autosuture) (27 patients); and (4) adhesive sutureless skin closure ("Op-site") (30 patients).

All wounds were examined by two independent observers at five, 10, and 45 days after operation. At five days, inflammation, extent of oedema, discharge, and infection were assessed. At 10 days attention was paid to the state of wound healing and at 45 days to the final cosmetic appearance. The use of continuous subcuticular suture resulted in significantly less discharge than did the use of metal staples, nylon vertical mattress suture, or Op-site. The incidence of established wound infection was $4.5 \%$ overall, with no infection in the wounds closed with Dexon. Assessment of the healing process showed subcuticular Dexon to be more effective than metal staples or vertical mattress nylon suture. The final cosmetic result showed continuous subcuticular suture to be superior to nylon vertical mattress suture and skin staples but as effective as Op-site sutureless skin closure.

Coronary artery bypass grafting is now one of the most commonly performed operations in the world. The most widely used conduit for bypassing the obstructed coronary artery is still a reversed segment of the patient's own long saphenous vein, and no synthetic substitute has yet been found that gives results as good as, let alone better than, autologous vein.' Nevertheless, removal of the entire long saphenous vein is necessary for multiple grafts and requires a long incision in the leg from ankle to groin. ${ }^{2}$ Despite complications from this wound possibly being troublesome and protracted, this part of the operation is often delegated to a junior member of the surgical team. Surprisingly little attention has been paid to the leg wound in coronary artery bypass grafting operations and in particular to the best method of skin closure. We report here the results of a prospective, randomised study of four different methods of leg wound skin closure.

Address for reprint requests: Dr GD Angelini, The Cardiac Surgical Department, University Hospital of Wales, Heath Park, Cardiff.

Accepted 18 July 1984

\section{Methods}

One hundred and thirteen patients undergoing coronary artery bypass grafting were allocated by serial number to four groups, which were comparable for age, sex, body weight, and length of leg incision (table 1). Multiple skin incisions with intervening skin bridges were not used. The small number of women studied reflected the predominant incidence of coronary artery disease in men.

All leg incisions were closed by the same surgeon $\frac{D}{0}$ after protamine had been given following the period of cardiopulmonary bypass, and in all cases the deep $N$ layer of the wound was approximated with continu- $N$ ous 2/0 Dexon suture after the insertion of one or $\mathcal{N}^{\circ}$ two Redivac drains. After the skin edges had been $\omega$ cleaned with iodine solution the skin was closed with: (1) a continuous vertical mattress suture of $2 / 0 \stackrel{\circ}{\complement}$ nylon (monofilament polyamide; Ethicon, Edinburgh) (27 patients); (2) a continuous subcuticular $\stackrel{+}{+}$ suture of $2 / 0$ polyglycolic acid (Dexon; Davis and $\frac{0}{\circ}$ Geck, Fareham) (29 patients); (3) disposable metal $\stackrel{\vec{D}}{\circ}$ skin staples (Premium; Autosuture UK, Ascot) (27 patients); or (4) "Op-site" sutureless skin closure $\stackrel{\square}{\circ}$ 


\begin{tabular}{lllll}
\hline & \multicolumn{2}{l}{ Patients whose wounds were closed with: } \\
\cline { 2 - 5 } & $\begin{array}{l}\text { Nylon } \\
(n=27)\end{array}$ & $\begin{array}{l}\text { Dexon } \\
(n=29)\end{array}$ & $\begin{array}{l}\text { Staples } \\
(n=27)\end{array}$ & $\begin{array}{l}\text { Op-site } \\
(n=30)\end{array}$ \\
\hline Mean (SD) age (y) & $55(8 \cdot 2)$ & $55(9 \cdot 3)$ & $49(14 \cdot 1)$ & 21 \\
No of men & 24 & 27 & $73(9 \cdot 1)$ & 28 \\
Mean (SD) weight (kg) & $70(8 \cdot 6)$ & $71(7 \cdot 6)$ & $45 \cdot 5(18 \cdot 1)$ & $70(8 \cdot 4)$ \\
Mean (SD) wound length (cm) & $47 \cdot 1(14 \cdot 5)$ & $46 \cdot 6(15 \cdot 4)$ & $51(15 \cdot 3)$ \\
\hline
\end{tabular}

(Medium drape, $30 \mathrm{~cm} \times 28 \mathrm{~cm}$; Smith and Nephew Medical, Birmingham) (30 patients).

All wounds apart from those closed with Op-site were covered with a light cotton gauze dressing and, after removal of Redivac drains 24 hours later, elastic antithrombotic stockings were worn on both legs. A standard antibiotic regimen (cefuroxime $750 \mathrm{mg}$ and gentamycin $80 \mathrm{mg}$ intravenously every eight hours) was used for all the patients until removal of the last chest drain. Leg movement was encouraged from the time of recovery of consciousness as was walking about from the second day.

All leg wounds were assessed by independent observers at five, 10 , and 45 days after operation. After five days wounds were examined for inflammation, extent of oedema, discharge, and infection (purulent discharge growing pathogenic organisms). The observer attempted to allocate a score for the first three of these variables on an incremental scale from 0 to 4 . On day 10 the observer commented on the state of wound healing, categorising the wound as "well healed," "healed with residual inflammation," showing "skin overlap," or showing "skin dehiscence." Patients were followed up five weeks after discharge when, during a routine postoperative visit, the outpatient sister graded the final cosmetic result as excellent, good, fair, or poor. Patients were also invited to give their own subjective assessment.

STATISTICAL METHODS

Wound healing assessed on day 10 was dichoto- mised to compare grade 1 (well healed) with all other grades and was analysed by $\chi^{2}$ on $3 \mathrm{df}$ (comparing four groups) and $\chi^{2}$ on $1 \mathrm{df}$ (comparing each pair of groups). Each other variable was analysed assuming an ordinal scale, so that the KruskalWallis test was used to compare four groups and the Mann-Whitney test to compare pairs of groups. Results were expressed as mean (SD).

\section{Results}

Day 5 (table 2) Wound discharge was significantly less in the wounds closed with subcuticular Dexon than in those closed with metal staples $(p<0.05)$, nylon vertical mattress suture $(p<0.01)$, or Op-site $(p<0.001)$. The extent of postoperative swelling of the wound edges was not influenced by the methods of closure used in the study. As far as inflammation was concerned, both subcuticular Dexon and Opsite were significantly better than nylon vertical mattress suture $(p<0.001)$ or metal staples $(p<0.05)$. The incidence of established wound infection was low ( $4.5 \%$ overall), with no infection in the wounds closed with subcuticular Dexon.

Day 10 (table 3) Visual assessment of the healing process showed subcuticular Dexon to be more effective in closing the wound than metal staples ( $p$ $<0.05)$ or vertical mattress nylon suture $(\mathrm{p}<0.05)$. Analysis of the other methods of skin closure showed no difference in wound healing between the three groups.

Day 45 (table 4) Independent assessment of the

Table 2 Mean (SD) score (graded 1-4) of variables and incidence of infection at observation on day 5 of wounds in four groups of patients

\begin{tabular}{|c|c|c|c|c|}
\hline & \multicolumn{4}{|c|}{ Patients whose wounds were closed with: } \\
\hline & $\begin{array}{l}\text { Nylon } \\
(n=27)\end{array}$ & $\begin{array}{l}\text { Dexon } \\
(n=29)\end{array}$ & $\begin{array}{l}\text { Staples } \\
(n=27)\end{array}$ & $\begin{array}{l}\text { Op-site } \\
(n=30)\end{array}$ \\
\hline $\begin{array}{l}\text { Discharge } \\
\text { Oedema } \\
\text { Inflammation } \\
\text { Infection }\end{array}$ & $\begin{array}{l}1.8(0.7) \\
1.9(0.8) \\
2 \cdot 1(0.8) \\
2\end{array}$ & $\begin{array}{l}1.2(0.5) \\
1.5(0.6) \\
1.5(0.7) \\
0\end{array}$ & $\begin{array}{l}1.6(0.8) \\
1.8(0.8) \\
1.9(0.8) \\
1\end{array}$ & $\begin{array}{l}2.2(0.8) \\
1.6(0.8) \\
1.5(0.7) \\
1\end{array}$ \\
\hline
\end{tabular}


Table 3 Number (\%) of patients in whom wounds were well healed or showed residual inflammation, skin overlap, or dehiscence on day 10

\begin{tabular}{llll}
\hline Grade of wound healing & \multicolumn{1}{l}{ Patients whose wounds were closed with: } \\
\cline { 2 - 4 } & $\begin{array}{l}\text { Nylon } \\
(n=27)\end{array}$ & $\begin{array}{l}\text { Dexon } \\
(n=29)\end{array}$ & $\begin{array}{l}\text { Staples } \\
(n=27)\end{array}$ \\
\hline Well healed & $7(26)$ & $18(62)$ & $8(30)$ \\
Residual inflammation & $14(52)$ & $10(35)$ & $13(50)$ \\
Skin overlap & $2(8)$ & $1(4)$ & $3(11)$ \\
Dehiscence & $4(15)$ & $3(11)$ & $13(44)$ \\
\hline
\end{tabular}

Table 4 Number (\%) of patients in each of four treatment groups in whom cosmetic results of wound healing were excellent, good, fair, or poor on day 45

\begin{tabular}{llccc}
\hline Cosmetic result & \multicolumn{4}{l}{ Patients whose wounds were closed with: } \\
\cline { 2 - 5 } & $\begin{array}{l}\text { Nylon } \\
(n=27)\end{array}$ & $\begin{array}{l}\text { Dexon } \\
(n=29)\end{array}$ & $\begin{array}{l}\text { Staples } \\
(n=27)\end{array}$ & $\begin{array}{l}\text { Op-site } \\
(n=30)\end{array}$ \\
\hline Excellent & $7(26)$ & $19(66)$ & $8(30)$ & $14(47)$ \\
Good & $11(39)$ & $9(30)$ & $13(48)$ & $13(43)$ \\
Fair & $8(30)$ & $1(4)$ & $5(18)$ & $3(10)$ \\
Poor & $1(4)$ & $1(4)$ & \\
\hline
\end{tabular}

Table 5 Variables of wound closure measured intraoperatively

\begin{tabular}{lllll}
\hline & \multicolumn{2}{l}{ Patients whose wounds were closed with: } & \\
\cline { 2 - 5 } & $\begin{array}{l}\text { Nylon } \\
(n=27)\end{array}$ & $\begin{array}{l}\text { Dexon } \\
(n=29)\end{array}$ & $\begin{array}{l}\text { Staples } \\
(n=27)\end{array}$ & $\begin{array}{c}\text { Op-site } \\
(n=30)\end{array}$ \\
\hline $\begin{array}{l}\text { Total wound length }(\mathrm{cm}) \\
\begin{array}{c}\text { Duration of skin closure } \\
(\mathrm{s} / 10 \mathrm{~cm} \text { of wound }\end{array}\end{array}$ & 1269 & 1380 & 1228 & 1530 \\
$\begin{array}{c}\text { length) } \\
\begin{array}{c}\text { Mean cost (p/10 cm of } \\
\text { wound length) }\end{array}\end{array}$ & 144 & 264 & 72 & 36 \\
\hline
\end{tabular}

final cosmetic result of skin closure of the leg wound showed subcuticular Dexon to be superior to the vertical mattress nylon or skin staples $(p<0.05)$ but as effective as Op-site sutureless skin closure. The patients' own assessment of the cosmetic results correlated with the independent assessment.

\section{INTRAOPERATIVE VARIABLES}

Table 5 shows variables measured intraoperatively. The total length of all leg wounds was similar for each group, but the average time taken to close 10 $\mathrm{cm}$ of skin in each group differed greatly. The Dexon method was by far the slowest, and Op-site, not surprisingly, the most rapid. As far as cost per 10 $\mathrm{cm}$ was concerned, Dexon was fairly expensive at $72 p$, but cost much less than staples (360p). The cheapest method was nylon (15p).

\section{Discussion}

Complications in the healing of the leg wound after coronary artery bypass grafting are discouraging for patients because their stay in hospital is prolonged and they may spend the next few weeks limping around unable to enjoy the benefits of otherwise successful coronary artery surgery. Although it is important that these incisions are made and closed properly, it is even more important that the saphenous vein is carefully extracted for grafting. It therefore seemed appropriate to search for the best method of closing the skin of the leg wound. The ideal method of skin closure should provide accurate apposition of the edges until they hold sufficiently well by themselves, ${ }^{3}$ but without undue tension, should cause minimal tissue reaction and discharge, and any suture material used should be cheap, easy and quick to insert and ideally should not need to be removed. From the patient's point of view the wound should be as comfortable as possible and have an acceptable appearance.

Continuous vertical mattress nylon suture Although cheap and easy to insert and giving good haemostasis, continuous vertical mattress nylon suture tends to become tight as wound oedema 
develops and therefore causes discomfort. In addition epidermal cells may be introduced into the deeper layers of the wound along the needle track, resulting in increase in incidence of infection. ${ }^{4}$ Cosmetically the final result is poor with lines of puncture holes parallel to the incision, and removal of the suture may be troublesome to both patient and nurses.

Continuous subcuticular suture, first described by Halsted in $1890,{ }^{5}$ may relieve tension of the wound edges and thereby limit the width of the scar. ${ }^{6}$ With Dexon this suture scores over all the others except in regard to cost and speed of insertion. It causes little tissue reaction and consequently looks neat and feels comfortable. It does not require removal, and this was certainly the favourite method with ourselves, patients, and nurses.

Metal skin staples were found to be quick to insert but expensive. The metal hooks leave a pinpoint mark but again increase tension and discomfort. Often the clips are difficult to remove, especially if they have been pressed too firmly into the skin.

Op-site sutureless skin closure has been proposed as a substitute for skin sutures. ${ }^{78}$ We found it quick to apply, although the skin must be absolutely dry and some practice is needed to achieve a good skin edge apposition. This method also appears to encourage wound exudation, and collections of fluid under the membrane may have to be aspirated. In two patients skin blisters developed, presumably of allergic origin. The Op-site had to be removed and the incision resutured.
The continuous subcuticular Dexon suture undoubtedly gave the best results in this study for skin closure after removal of the long saphenous vein from the leg. It was superior to the other methods by all the criteria listed above with the exception of cost and speed of insertion. These considerations seem relatively unimportant in comparison with the benefits of this method, and we recommend it for standard use in all cases.

\section{References}

1 Sapsford RN, Oakley GD, Talbot S. Early and late patency of expanded polytetrafluoroethylene vascular grafts, in aorto-coronary bypass. J Cardiovasc Surg 1981;81:860-4.

2 Rob C, Smith R. Operative surgery. 3rd ed. London: Butterworths, 1978:202-3.

3 Peacock EE, Van Winkle HW. Surgery and biology of wound repair. Philadelphia: Saunders, 1970:184.

4 Gillman T, Penn J. Studies on the repair of wound with reference to epidermal reaction to sutures and pathogeneses of carcinoma in scars. Medical Practice 1956;suppl 2:121-49.

5 Halsted WH. Radical cure of hernia. Johns Hopkins Hospital Medical Journal 1890;1:13.

6 Straith RE, Lawson JH, Hipps CJ. The subcuticular suture. Postgrad Med 1961;29:164.

7 Westaby S. Evaluation of a new product for sutureless skin closure. Ann R Coll Surg Engl 1980;62:129-32.

8 Watson GM, Anders CJ, Glover JR. Op-site skin closure: A comparison with subcuticular and interrupted sutures. Ann R Coll Surg Engl 1983;65:83-4. 